\title{
What Influences Employer Branding More? Organizational Commitment or Organizational Culture? ${ }^{1}$
}

\author{
Jaafar Ali Akbar AL-KHOJA², Arzu GİRİŞKEN ${ }^{3 *}$ \\ Geliş Tarihi/Received: 01.04.2021 \\ Kabul Tarihi/Accepted: 07.04.2021 \\ Araştırma Makalesi/Research Article
}

\begin{abstract}
Companies and organizations are searching hard enough to improve business performance. It is more apparent in the 21 st century that employees are the most critical assets of organizations. Organizations that need to enroll gifted employees should stay aware of the competitive environment and keep the current high-caliber staff. By utilizing the endeavors' employer image and bonding emotionally with the employees, the probability that quality workers are held in the company is high. This quantitative research focused on the impacts of hierarchical culture and authoritative commitment on employer branding. The study is significant to shed light on the factors that influence employer branding. The exciting finding of this research is that organizational culture has a more substantial impact on employer branding than organizational commitment. The same finding can be significant for business professionals' employer branding efforts and academics working in the employer branding concept.
\end{abstract}

Keywords: Organizational Culture, Employer Branding, Organizational Commitment JEL codes: M5, M12, M100.

\footnotetext{
${ }^{1}$ This study is adopted from the master thesis named "The effect of organizational culture and organizational commitment on employer's brand" defended in 2019 at Altınbaş University."

${ }^{2}$ Master's Degree Student, Altınbaş University, Orcid No: 0000-0001-6140-1543

${ }^{3}$ Asst. Prof., Altınbaș University, Faculty of Business Administration, Orcid No: 0000-0003-0295-7976

* Sorumlu yazar/Corresponding author

E-mail/e-ileti: cakar.arzu@gmail.com
} 


\section{İşveren Markası Üzerinde Hangisi Daha Çok Etkili? Örgütsel Bağlılık mı, Örgüt Kültürü mü?}

\section{ÖZET}

Şirketler ve kurumlar, iş performanslarını artırmak için sürekli araştırma yapmaya devam ediyor. Günümüzde artık çalışanların, kuruluşların en önemli değeri olduğu anlaşılmıştır. Sert rekabet koşullarında başarılı olmak isteyen kurumlar, üstün yetenekli çalışanları için kurum bağ lılığını artırmak ve yetenekli potensiyel çalışanları da şirketlerine çekmek istiyor. Bu durum, mevcut çalışanların bilgi ve beceri seviyesini yüksek tutarak performanslarını sürekli artırmayı da zorunlu kılıyor. Başarılı çalışanların elde tutulması ve potansiyel çalışanların da kuruma talepte bulunması için işveren imajını kullanmak ve (potansiyel) çalışanlarla duygusal bağ kurmak hızla gelişen paradigmaların içerisinde yer alıyor. Bu nicel araştırma, hiyerarşik kültürün ve organizasyona bağlılı̆̆ın, işveren markası üzerindeki etkilerine odaklandı. Bu çalışmanın çıktıları, işveren markasını etkileyen faktörlere 1şık tutması bakımından daha önce gerçekleştirilen araştırmalardan farklılık içermektedir. $\mathrm{Bu}$ araştırmanın ilgi çekici bulgusu; örgütsel kültürün, örgütsel bağlılığa kıyasla işveren markası üzerinde daha güçlü bir etkiye sahip olmasıdır. Bu bulgu, işveren markasını güçlendirme çabası içinde olan profesyoneller ve işveren markası kavramına odaklanan akademisyenler için önemli olabilir.

Anahtar Kelimeler: Örgüt Kültürü, İşveren Markası, Örgütsel Bağl1lık

JEL Kodları: M5, M12, M100

\section{INTRODUCTION}

Organizational structure is covering all human values, economic, cultural, etc., in today's life. It is affected by events. Therefore, the organization aims to be in harmony with people and the whole environment. It also wants to have a power called organizational culture for organizational purposes (Schein, 2010: 118).

It is possible to express organizational culture as a framework that combines cultural values, philosophical assumptions, people's beliefs, and expectations (Iivari and Iivari, 2011: 509). Thus, organizational culture is a community that is of great importance in shaping the members' behavior and thinking structure organizations behavior and thinking structures. 
Organizational culture is a broad concept that is also associated with organizational addiction. Organizational dependence of individuals is the adoption of an employer brand definition. This definition includes active human resources activities and those with a specific purpose and working group (Armstrong, 2011: 20). The employer brand is at a level to interfere with internal problems and events. With this aspect, the business becomes attractive both inside and outside. Thanks to employer branding, the quality of the workforce increases. Indirectly, the customer base and market power of the enterprise also increase. Besides, it is thanks to the employer branding that they remain competitive with competitors (Dabirian et al., 2019: 82). As a result, all these benefits increase employees' commitment to the organization.

Organizations find equipped employees and keep them connected to the companies due to the high competition environment and the limited number of qualified staff. For this reason, organizations must acquire an employer brand with a strong structure, and which will attract employees (Backhaus and Tikoo, 2004: 501). The concept of organizational commitment emerged as a result of employer brand activities. Employees with a high organizational commitment level (Dabirian et al., 2019: 84) positively affect their work desire, performance, and contribution to work.

In this study, the effect of employees' and managers' organizational culture and organizational commitment level on employer branding will be analyzed for Turkish companies. A conceptual framework will be drawn before analyzing the variables. In this context, various scales will determine the individual's attractiveness when applying for a job and define employees' organizational culture and organizational commitment. Also, the scope of this relationship will be expanded with demographic features.

In this research, an analysis will be made to see the effect of employer branding studies on the relationship between companies' organizational culture and commitment in the automotive sector. Additionally, examining the perception of employer branding activities was also the focus of this study. It will also be discussed in this context that employer branding variables are considered essential and prioritized by the employees. In this way, it aims to contribute to the academic literature by focusing on Turkey's automotive sector's business case. The main reason for selecting the automobile sector is that this sector's players have global extends. Therefore the findings could be adopted by different branches of automobile companies all over the world. Additionally, the number of employees relatively 
high in this sector will have various dimensions as they will be vastly discussed in the following sections.

\section{CONCEPTUAL FRAMEWORK}

This part of the study was created to establish the conceptual infrastructure of the analysis variables.

\subsection{Organizational Culture}

In the first studies aimed at defining the organizational culture, the essential elements of organizational culture were emphasized, and cultural values and norms affect behaviors and socialization were prioritized. The same points are included in the concept of organizational culture, which is tried to be defined today, but the issue is approached from a broader perspective. The management of corporate culture has been explored in the management sciences and researchers and scientists from different disciplines such as communication, psychology, sociology, social psychology, political science, and socio-cultural anthropology (Vural, 2003: 20).

As a result of its research by different disciplines, the most general definition that can be made for organizational culture is a whole consisting of common thoughts, beliefs, and values that regulate the social and economic relations of the members of the organization and solve their problems (Güney, 2011:36).

According to Eren (2004: 23), organizations consist of individuals with different cultural mosaics who try to make a general definition. These individuals, combined with mission and professional norms and measures, form a system of beliefs and values that are different from other organizations as a natural result of forming a group but in themselves. This created system helps different beliefs, values, attitudes, ways of thinking, and moral understanding coexist within the organization, known as organizational culture.

The studies conducted for determining the organizational culture types have come up with various alternatives. However, bureaucratic culture and innovative culture can be described as the most general classifications (Demir, 2011: 40).

\subsection{Organizational Culture and Business Attitude}

A close relationship between organizational culture and business attitude makes this concept more important in an organization's existence and continuity. 
Attitudes are the hidden forces that drive the behaviors. Therefore, it has been studied how attitudes are formed and how they can guide behaviors in various cases. Thus, understanding how attitudes emerge will make it easier to anticipate the possible behaviors of the employees. Besides, how an attitude will be changed can be learned in the process; therefore, it will be possible to enhance the organizations' performance by predicting and transforming the negative behaviors into positive ones (Baysal and Tekarslan, 1996:48). The components that form the attitudes can be grouped under three segments: cognitive, affective, and behavioral (Erdoğan, 1999: 56).

The alienated employees will quit whenever they find chances (Greenberg and Baron, 2000: 78). Wrapping work, which is one of the attitudes in organizational behavior, is a situational factor associated with satisfaction arising from a commitment to work and profession (Balay, 2012: 2474). Employees with a high level of employment identify themselves strongly with their organizations to increase their performance. Performance rates will reduce absenteeism rates (Robbins and Judge, 2007: 57). On the other hand, organizational commitment is one of the most important indicators of organizational efficiency and effectiveness that intends to remain among the attitude variables. The stronger the strength of their bond with their organizations, the more willing and efficient employees are to adopt and work for their organization's values and goals (Porter et al., 1974: 603).

\subsection{Organization Commitment}

Employee commitment is a subjective concept defined in different ways. However, based on the individual's perception of work experience, strong emotions, and attitudes he creates towards his work. One of the most used employee loyalty definitions was made by Locke. Locke (1976: 1297) defined employee loyalty as the appreciation of a person's job or work life as a situation that results in a satisfactory or positive emotion. Some of the other definitions for employee commitment are:

- psychological and environmental conditions that ensure one's job satisfaction (Hoppock, 1935: 78),

- subjectively assessing the degree of fulfillment of the work done by the employees and the emotional response to the person's work (Chappell, 2011: 82),

This concept, which is intertwined with organizational culture, helps to minimize problems such as disruption of work and disruption in the organization due to the organization's goals and tools. Besides, those who work in places with high employee loyalty become part of the solution by making an extraordinary effort in case of an unexpected 
problem or in times of crisis. In this way, organizations that meet the employees' expectations do not have difficulty finding personnel (Özkalp and Kırel, 2010: 38).

\subsection{Employer Branding}

Employer brand attracts attention as an issue for today's institutions. The employer brand is generally defined as the process of creating an original image of an institution in the eyes of its current and potential employees. The employer brand (Mokina, 2014: 136), which characterizes the organization as an employer and is associated with employment characteristics, is included in the belief systems of potential and existing employees of the organization (Collins and Kanar, 2013) and both towards the employment market outside (Mokina, 2014: 140).

In job application processes, people search for being part of the institutions where they share the same/similar attitudes, ideas, and values. At the same time, organizations choose candidates who have similar characteristics (Bonaiuto et al., 2013: 779). From this point of view, the employer brand establishes a basis for a relationship between 'organizations' existing employees and new employees (Küçükgökdemir and Bal, 2018: 1093).

Both existing employees and new employees can be attracted by an organization's concrete and symbolic brand qualities (Bonaiuto et al., 2013: 784). According to Van Hoye et al. (2013: 543), the practical side of the employer brand (such as working conditions) and symbolic images (such as adequacy) can be associated positively with organizational attractiveness. So that not only the concrete elements but also emotional affection are essential to appeal to existing and potential employees. Tatar et al. (2018: 346) found that the employer brand "affects employees' sense of dedication, organizational support, and job embeddedness" in their study. Emphasizing the importance of existing employees in the employer branding process, Wolf et al. (2015: 16) state that employees are a key stakeholder with multiple roles and explain these roles as follows:

- Consumers of corporate brand identity: Many branding activities are directed to employees.

- Co-creator: It actively shapes the institution's identity.

- Employer brand carrier Represents the organization against consumers, partners, new employees, families 


\section{RESEARCH HYPOTHESIS AND METHODOLOGY}

As organizations move into an environment without borders, it has become increasingly important to attract, engage, develop and retain talents (Lockwood, 2007: 42). Maintaining an organizations' competitiveness requires a more significant employee commitment (Burke and Cooper, 2006: 83). Barrow and Mosley (2005: 45) explain the three main reasons for developing the employer brand: Organizations increasingly realize that their employees' commitment and loyalty are not easy. Businesses also require a more focused, compliant, and beneficial approach than in the past to attract the right people, encourage them for loyalty, and apply the best of their abilities. In this context, the H1 was formed in this study how the employer brand's offering career opportunities will affect this relationship:

- H1: Organizational Culture and Organizational Commitment affect Career Opportunity \& Development positively.

- Hla: Organizational Culture affects Career Opportunity \& Development positively.

- H1b: Organizational Commitment affects Career Opportunity \& Development positively.

In this way, it will be investigated how to meet the employee's career expectation, how culture and commitment being affected in a large workplace that is compatible with his values and ideals (Bruce and Harvey, 2010: 47). Employer branding provides an effective commercial bridge between human resources, internal communication, and marketing. Many businesses have become aware of recruiting the right people, keeping them in the organization, and developing. In this context, the organization's characteristics are of great importance, leading us to create $\mathrm{H} 2$.

- H2: Organizational Culture and Organizational Commitment affect Working Environment positively.

- H2a: Organizational Culture affects Working Environment positively.

- H2b: Organizational Commitment affects Working Environment positively.

In addition to financial expectations, employees are increasingly looking for an organization that is sensitive to their values and the environment they work in and that they can adapt to with the service they provide to customers (Minchinglon and Thome, 2007:14). Hence, Organizational Features made it possible to add $\mathrm{H} 3$ to the hypotheses of this study on how effective it is. 
- H3: Organizational Culture and Organizational Commitment affect Organization Features positively.

- H3a: Organizational Culture affects Organization Features positively.

- H3b: Organizational Commitment affects Organization Features positively.

In the labor market, candidates can be very meticulous about where they will work. Sometimes this is about salary or benefits. H4 was created to see this, in return, the organizational culture and commitment provided.

- H4: Organizational Culture and Organizational Commitment affect Work and Life Balance positively.

- H4a: Organizational Culture affects Work and Life Balance positively.

- H4b: Organizational Commitment affects Work and Life Balance positively.

Besides, Ewing et al. (2002: 4) works, internal products; see employees as internal customers. Business products should attract, develop, and motivate employees so they meet internal customers' needs and desires while addressing the organization's entire purpose. In this context, work and personal life balance are of great importance. How this will affect the concepts in the research will be investigated with the $\mathrm{H} 5$ :

- H5: Organizational Culture and Organizational Commitment affect Salary and Other Financial Benefits positively.

- H5a: Organizational Culture affects Salary and Other Financial Benefits positively.

- H5b: Organizational Commitment affects Salary and Other Financial Benefits positively.

Companies' organizational culture in Turkey within the research scope and its impact on employer brand to the positive and negative organizational commitment levels were examined. To evaluate the issue more comprehensively, a quantitative survey method was conducted by face-to-face interviews with 411 managers (15\%) and employees (85\%) who work in the automobile sector in Istanbul. The sample tolerance of research findings is $5 \%$ in $95 \%$ confidence interval.

In the survey, seven questions were asked to determine the participants' demographic characteristics. Additionally, sixty questions created with a 5-point Likert type scale were asked to determine the individual's attractiveness when applying for a job. To determine the employees' organizational culture, 36 questions created with a 5-point Likert type scale were 
asked. Finally, the individual's organizational commitment is measured with 18 questions created by a 5-point Likert type scale. The details of the scales used are as follows:

The scale of employer branding: This scale was developed by Öksüz (2012: 67) with Grounded Theory and translated into Turkish and adapted. The scale of organizational commitment: There are 18 questions to measure employees' commitment to the organization. To evaluate the employees' organizational commitment (Wasti, 2000: 57; Çetin, 2006: 78), Meyer and Allen's three-dimensional organization commitment scale, which was previously translated into Turkish and tested for validity and reliability, was used. In this study, the scale's dimensions' reliability coefficients are as follows: alpha 0.64 for emotional commitment, alpha 0.68 for continuity commitment, alpha 0.72 for normative commitment. The overall reliability coefficient of the scale was calculated as alpha 0.73 (Özutku, 2009: 79).

\section{RESULTS}

Frequency analysis was conducted to determine the distribution of demographic information of the participants. While $22.6 \%$ of the participants are managers, $77.4 \%$ are employees. Besides, the vast majority of the participants are married $(79.5 \%)$. Distribution by experience is evenly distributed: the proportion of those with 1-5 years of experience is $21.2 \%$, the proportion of those with experience of 6-10 years is $20 \%$, the proportion of those with experience of $11-15$ years $13.1 \%$ is the ratio of those who have experience for $16-20$ years and is $30.4 \%$, the rate of those who have experience for $21-30$ years is $11.9 \%$, and the rate of those who have $31+$ years experience is $3.4 \%$.

The sub-dimensions of employer brand, organizational culture, and organizational commitment scales were calculated based on the guidelines' steps. Additionally, descriptive statistics for these sub-dimensions were given to determine the relationship between the organizational culture and organizational commitment scales of the employer brand scale, a correlation analysis was performed, and a Pearson correlation coefficient was obtained.

The Work Environment sub-dimension, Business characteristics sub-dimension, Work and Life balance sub-dimension, and the Salary and Other Material Benefits sub-dimension have a positive and significant relationship with the levels of participation, consistency, adaptability, mission sub-dimensions at the levels specified in Table 1. There is no significant relationship between these sub-dimensions and organizational commitment scale subdimensions. 
To determine the effect of organizational culture and organizational commitment scales on the employer brand, five regression models in which the sub-dimensions of the employer brand scale were taken as dependent variables, and the organizational commitment scale and organizational commitment scale sub-dimensions, respectively, were established and tested (Table 2 and Table 3).

Table 1. Correlation analysis results

\begin{tabular}{|c|c|c|c|c|c|c|}
\hline & & $\begin{array}{c}\text { Career } \\
\text { Opportunities } \\
\text { and } \\
\text { Development }\end{array}$ & $\begin{array}{c}\text { Working } \\
\text { Environment }\end{array}$ & $\begin{array}{l}\text { Organization } \\
\text { Features }\end{array}$ & $\begin{array}{l}\text { Work } \\
\text { and } \\
\text { Life } \\
\text { Balance }\end{array}$ & $\begin{array}{c}\text { Salary and } \\
\text { Other } \\
\text { Financial } \\
\text { Benefits }\end{array}$ \\
\hline \multirow{2}{*}{ Participation } & $\mathbf{r}$ & $.849 * *$ & $.793 * *$ & $.767 * *$ & $.751 * *$ & $.810 * *$ \\
\hline & $\mathbf{p}$ & .000 & .000 & .000 & .000 & .000 \\
\hline \multirow{2}{*}{ Consistency } & $\mathbf{r}$ & $.889 * *$ & $.894 * *$ & $.856 * *$ & $.819 * *$ & $.827 * *$ \\
\hline & $\mathbf{p}$ & .000 & .000 & .000 & .000 & .000 \\
\hline \multirow{2}{*}{ Adaptability } & $\mathbf{r}$ & $.900 * *$ & $.887 * *$ & $.920 * *$ & $.928 * *$ & $.844 * *$ \\
\hline & $\mathbf{p}$ & .000 & .000 & .000 & .000 & .000 \\
\hline \multirow{2}{*}{ Mission } & $\mathbf{r}$ & $.812 * *$ & $.771 * *$ & $.669 * *$ & $.648 * *$ & $.771 * *$ \\
\hline & $\mathbf{p}$ & .000 & .000 & .000 & .000 & .000 \\
\hline \multirow{2}{*}{$\begin{array}{c}\text { Emotional } \\
\text { Commitment }\end{array}$} & $\mathbf{r}$ & .002 & .052 & .048 & .020 & .056 \\
\hline & $\mathbf{p}$ & .962 & .294 & .335 & .682 & .257 \\
\hline \multirow{2}{*}{$\begin{array}{l}\text { Continuance } \\
\text { Commitment }\end{array}$} & $\mathbf{r}$ & -.026 & .007 & .013 & .009 & -.009 \\
\hline & $\mathbf{p}$ & .595 & .894 & .798 & .853 & .859 \\
\hline \multirow{2}{*}{$\begin{array}{c}\text { Normative } \\
\text { Commitment }\end{array}$} & $\mathbf{r}$ & -.026 & .007 & .023 & .027 & -.011 \\
\hline & $\mathrm{p}$ & .594 & .894 & .646 & .587 & .824 \\
\hline
\end{tabular}

The first regression model (Table 2), in which the sub-dimensions of career opportunities and development, and sub-dimensions of organizational culture and organizational commitment scale, were taken as independent variables $(F=861,049 ; p$ $<0.01)$. The rate of independent variables to explain dependent variables is $93.7 \%$. When the significance levels of parameter coefficients in the model are examined, the sub-dimensions of the organizational culture scale significantly affect the career opportunities and development and the sub-dimensions of the organizational commitment scale did not significantly affect the career development and opportunities. 
Table 2. Regression analysis results (model 1,2,3)

\begin{tabular}{|c|c|c|c|c|c|c|}
\hline \multirow{2}{*}{\begin{tabular}{|l} 
\\
Models
\end{tabular}} & & \multicolumn{2}{|c|}{$\begin{array}{l}\text { Unstandardized } \\
\text { Coefficients }\end{array}$} & \multirow{3}{*}{$\begin{array}{c}\begin{array}{c}\text { Standardized } \\
\text { Coefficients }\end{array} \\
\text { Beta }\end{array}$} & \multirow{3}{*}{$\begin{array}{c}\mathrm{t} \\
-0.105\end{array}$} & \multirow{3}{*}{$\begin{array}{c}\mathrm{p} \\
0.917\end{array}$} \\
\hline & & $\mathrm{B}$ & Std. Error & & & \\
\hline \multirow{4}{*}{ (Model 1) } & Constant & -0.006 & 0.057 & & & \\
\hline & Participation & 0.086 & 0.037 & 0.093 & 2.299 & $0.022 *$ \\
\hline & Consistency & 0.352 & 0.023 & 0.363 & 15.193 & $0.000 *$ \\
\hline & Adaptability & 0.402 & 0.024 & 0.443 & 16.660 & $0.000^{*}$ \\
\hline \multirow{4}{*}{$\begin{array}{l}\text { Career Opportunities } \\
\text { and Development } \\
\mathrm{F}=\mathbf{8 6 1 . 0 4 9} ; \mathbf{p}=\mathbf{0 . 0 0 0} * \\
\mathrm{R} 2=\mathbf{0 . 9 3 7}\end{array}$} & Mission & 0.166 & 0.036 & 0.169 & 4.585 & $0.000 *$ \\
\hline & Emotional Commitment & -0.017 & 0.015 & -0.029 & -1.123 & 0.262 \\
\hline & $\begin{array}{l}\text { Continuance } \\
\text { Commitment }\end{array}$ & 0.003 & 0.019 & 0.004 & 0.145 & 0.885 \\
\hline & Normative Commitment & 0.004 & 0.017 & 0.006 & 0.267 & 0.790 \\
\hline
\end{tabular}

\begin{tabular}{|c|c|c|c|c|c|c|}
\hline \multirow{8}{*}{$\begin{array}{l}\text { (Model 2) } \\
\text { Working } \\
\text { Environment } \\
\text { F=610.561; } \\
\text { p=0.000* } \\
\text { R2 }=0.914\end{array}$} & Constant & 0.040 & 0.067 & & 0.597 & 0.551 \\
\hline & Participation & -0.067 & 0.044 & -0.072 & -1.530 & 0.127 \\
\hline & Consistency & 0.411 & 0.027 & 0.423 & 15.100 & $0.000^{*}$ \\
\hline & Adaptability & 0.453 & 0.028 & 0.498 & 15.962 & $0.000^{*}$ \\
\hline & Mission & 0.189 & 0.042 & 0.192 & 4.443 & $0.000^{*}$ \\
\hline & $\begin{array}{l}\text { Emotional } \\
\text { Commitment }\end{array}$ & 0.040 & 0.018 & 0.067 & 2.221 & $0.027^{*}$ \\
\hline & $\begin{array}{l}\text { Continuance } \\
\text { Commitment }\end{array}$ & -0.025 & 0.022 & -0.037 & -1.139 & 0.255 \\
\hline & $\begin{array}{l}\text { Normative } \\
\text { Commitment }\end{array}$ & -0.003 & 0.020 & -0.004 & -0.152 & 0.879 \\
\hline
\end{tabular}

\begin{tabular}{|l|l|c|c|c|c|c|}
\hline & Constant & -0.088 & 0.072 & & -1.215 & 0.225 \\
\cline { 2 - 7 } & Participation & 0.238 & 0.047 & 0.236 & 5.022 & $0.000^{*}$ \\
\cline { 2 - 7 } (Model 3) & Consistency & 0.490 & 0.029 & 0.465 & 16.693 & $0.000^{*}$ \\
\cline { 2 - 7 } $\begin{array}{l}\text { Organization } \\
\text { Features }\end{array}$ & Adaptability & 0.537 & 0.031 & 0.544 & 17.545 & $0.000^{*}$ \\
\cline { 2 - 7 } $\begin{array}{l}\text { F=618.991; } \\
\mathbf{p = 0 . 0 0 0}\end{array}$ & Mission & -0.266 & 0.046 & -0.249 & -5.804 & $0.000^{*}$ \\
\cline { 2 - 7 } $\mathbf{R 2 = 0 . 9 1 5}$ & $\begin{array}{l}\text { Emotional } \\
\text { Commitment }\end{array}$ & 0.032 & 0.019 & 0.049 & 1.647 & 0.100 \\
\cline { 2 - 8 } & $\begin{array}{l}\text { Continuance } \\
\text { Commitment }\end{array}$ & -0.027 & 0.024 & -0.036 & -1.129 & 0.260 \\
\cline { 2 - 8 } & $\begin{array}{l}\text { Normative } \\
\text { Commitment }\end{array}$ & 0.013 & 0.021 & 0.017 & 0.599 & 0.550 \\
\hline
\end{tabular}

The second regression model (Table 2), in which the sub-dimensions of the working environment were subordinated, and the organizational culture and organizational commitment scale sub-dimensions were taken as independent variables $(F=610,561 ; p$ 
$<0.001)$. The rate of independent variables to explain dependent variables is $91.4 \%$. When the significance levels of parameter coefficients in the model are examined; It was observed that the sub-dimensions of the organizational culture scale affect the working environment significantly and positively, while the sub-dimensions of the organizational commitment scale affect the working environment positively. In contrast, the other sub-dimensions did not affect the working environment sub-dimension significantly.

The third regression model (Table 2), in which the sub-dimensions of the enterprise characteristics sub-dimension, the organizational culture, and the organizational commitment scale sub-dimensions were taken as independent variables, was found significant $(\mathrm{F}=$ $618,991 ; \mathrm{p}<0.001)$. The rate of independent variables to explain dependent variables is $91.5 \%$. When the significance levels of parameter coefficients in the model are examined, the organizational commitment subscales did not affect the organizational commitment significantly.

Table 3. Regression analysis results (model 4,5)

\begin{tabular}{|c|c|c|c|c|c|c|}
\hline \multirow{2}{*}{\multicolumn{2}{|c|}{ Models }} & \multicolumn{2}{|c|}{$\begin{array}{l}\text { Unstandardized } \\
\text { Coefficients }\end{array}$} & \multirow{2}{*}{$\begin{array}{c}\begin{array}{c}\text { Standardized } \\
\text { Coefficients }\end{array} \\
\text { Beta }\end{array}$} & \multirow{2}{*}{$\mathbf{t}$} & \multirow{2}{*}{$\mathbf{p}$} \\
\hline & & B & Std. Error & & & \\
\hline \multirow{8}{*}{$\begin{array}{l}\text { (Model 4) } \\
\text { Work and Life } \\
\text { Balance } \\
F=509,206 ; \\
\text { p=0,000 } \\
\text { R2=0,897 }\end{array}$} & Constant & $-0,065$ & 0,080 & & $-0,807$ & 0,420 \\
\hline & Participation & 0,120 & 0,053 & 0,117 & 2,288 & $0,023^{*}$ \\
\hline & Consistency & 0,362 & 0,033 & 0,338 & 11,111 & $0,000 *$ \\
\hline & Adaptability & 0,681 & 0,034 & 0,679 & 20,046 & $0,000 *$ \\
\hline & Mission & $-0,163$ & 0,051 & $-0,150$ & $-3,207$ & $0,001 *$ \\
\hline & $\begin{array}{l}\text { Emotional } \\
\text { Commitment }\end{array}$ & $-0,035$ & 0,021 & $-0,053$ & $-1,620$ & 0,106 \\
\hline & $\begin{array}{l}\text { Continuance } \\
\text { Commitment }\end{array}$ & $-0,005$ & 0,027 & $-0,006$ & $-0,183$ & 0,855 \\
\hline & $\begin{array}{l}\text { Normative } \\
\text { Commitment }\end{array}$ & 0,058 & 0,024 & 0,074 & 2,444 & 0,015 \\
\hline \multirow{8}{*}{$\begin{array}{l}\text { (Model 5) } \\
\text { Salary and Other } \\
\text { Financial Benefits } \\
\text { F=280,408; }=0,000 \\
\text { R2=0,830 }\end{array}$} & Constant & $-0,255$ & 0,106 & & $-2,410$ & $0,016^{*}$ \\
\hline & Participation & 0,154 & 0,069 & 0,148 & 2,228 & $0,026^{*}$ \\
\hline & Consistency & 0,353 & 0,043 & 0,325 & 8,230 & $0,000^{*}$ \\
\hline & Adaptability & 0,403 & 0,045 & 0,395 & 9,012 & $0,000 *$ \\
\hline & Mission & 0,142 & 0,067 & 0,128 & 2,114 & $0,035^{*}$ \\
\hline & $\begin{array}{l}\text { Emotional } \\
\text { Commitment }\end{array}$ & 0,093 & 0,028 & 0,140 & 3,298 & $0,001 *$ \\
\hline & $\begin{array}{l}\text { Continuance } \\
\text { Commitment } \\
\end{array}$ & $-0,066$ & 0,035 & $-0,086$ & $-1,879$ & 0,061 \\
\hline & $\begin{array}{l}\text { Normative } \\
\text { Commitment }\end{array}$ & $-0,032$ & 0,031 & $-0,040$ & $-1,026$ & 0,305 \\
\hline
\end{tabular}


The fourth regression model (Table 3), in which the sub-dimensions of work and life balance sub-dimensions and organizational culture and organizational commitment scale subdimensions were taken as independent variables, were found significant $(F=618,991 ; p$ $<0.001)$. The rate of independent variables to explain dependent variables is $91.5 \%$. When the significance levels of parameter coefficients in the model are examined, the sub-dimensions of the organizational culture scale significantly affect the work and life balance subdimension, while the sub-dimensions of the organizational commitment scale did not significantly affect career development and opportunities.

The second regression model (Table 3), in which the sub-dimension of Salary and Other Material Benefits was dependent, and the sub-dimensions of organizational culture and organizational commitment scale, were taken as independent variables $(F=280,408 ; p$ $<0.001)$. The rate of independent variables to explain dependent variables is $83 \%$. When the significance levels of parameter coefficients in the model are examined; It was observed that the sub-dimensions of the organizational culture scale affect the working environment significantly and positively, while the sub-dimension of the organizational commitment scale affects the salary and other material benefits sub-dimension. In contrast, the other subdimensions did not significantly affect the salary and other material benefits sub-dimension.

\section{DISCUSSION}

In the first of the created models, the 'career opportunities and development' dependent variable, organizational culture scale, and organizational commitment scale were determined as independent variables. It is seen that the model created as a result of the analysis is significant, and the level of explanation is high. "Working environment" in model 2, "organization features" in model 3, "work and life balance" in model 4, and "salary and material activities" in model 5 are determined as dependent variables. As a result of the analysis made, it was concluded that the models are meaningful, and the levels of explanation of the model are high. When we look at the literature about these results, it is possible to say that some results are similar, and some are different.

According to the results of the $\mathrm{H} 1$ constructed in the first model, the organizational culture positively affects the employer brand in the context of Career Opportunities and Development. The sub-dimension in which this relationship most vital was "adaptability." The external adaptation dimension can be explained as directing the strategic interest to the customers' demands and the external environment's requirements. In this cultural dimension, the importance of change skills necessary for organizations to quickly adapt to environmental 
changes is emphasized. The dimension of adaptation skills is perceived as an important goal for all employees to learn new information about their jobs.

It is seen that organizations are aware that gaining external adaptation skills can only be achieved by acquiring new information and that they aim to obtain further information with their work. The literature, Backhaus and Tikoo (2004: 504) state that institutions benefit from employer branding to influence the potential workforce and adapt existing employees to corporate culture and strategies. Schein (2010: 121) also states that the organizational culture that emerges during its adaptation to the external environment is related to the employer brand. In the literature, in the study of Ramdhani, Ramdhani, and Ainisyifa (2017:826), it was concluded that organizational culture has a significant impact on the employer brand. This is felt especially in the field of education and development, and communication.

There is a statistically insignificant relationship between organizational commitment and employer brand in terms of career opportunities in the analysis. However, in the literature, Kuruüzüm et al. (2010: 183) argue that career opportunities are effective in organizational commitment, saying that employees' level of commitment is affected by the human resources policies followed by institutions and generally by the attractiveness of outside job opportunities rather than being sectoral.

According to the results of the $\mathrm{H} 2$ constructed in the second model, the organizational culture positively affects the employer brand in the "adaptability" sub-dimension in terms of Working Environment and negatively in the "participation" sub-dimension. Besides, the "emotional commitment" has a positive relationship with the employer brand. When we examine the studies in the literature, Mowday et al. (1979: 224), it is claimed that work experience causes the employee to be competent in fulfilling his / her roles by satisfying the employee's psychological needs more than the other determinants and to feel satisfied in the organization.

Considering that most of the participants have high work experience, this result is consistent with the literature. Besides, in the study conducted by Kara (2013: 34), the relationship between the employer brand and the emotional commitment dimension of organizational commitment was examined. According to the analysis results, positive and significant relationships were found between all elements of the employer brand and emotional commitment. 
According to the results of the $\mathrm{H} 3$ hypothesis constructed in the third model, the organizational culture affects the employer brand positively in the "adaptability" subdimension in terms of Organization Features and negatively in the "mission" sub-dimension. Besides, in the analysis, organizational commitment and employer branding are in a statistically insignificant relationship. In the literature, this result coincides with Lockwood's (2007: 46) study, arguing that businesses that provide workplace culture are also successful in employer branding. According to the results of the H4 constructed in the fourth model, the organizational culture positively affects the employer brand in all sub-dimensions in terms of Work and Life Balance. Besides, in the analysis, organizational commitment and employer branding are in a statistically insignificant relationship. Regarding this first result in the literature, Tanwar and Prasad (2016: 854) mention the importance of work-life balance in the employer brand and argue that it is effective in corporate culture.

According to the results of the H5 constructed in the last model in the study, organizational culture positively affects the employer brand in the "adaptability" subdimension in the sense of Salary and Other Financial Benefits and negatively in the "mission" sub-dimension. Therefore, financial gain and fringe benefits can have a negative effect on the employer's brand perception. Generally, there is an opposite result in the literature. The argument of many is as follows: Human resources departments develop employer brands to attract candidates and keep their employees so that they can offer values such as corporate culture, mission, and ethical values that will differentiate the company by looking far beyond salary and additional benefits, and they have to manage the communication as a critical point.

Human resources are responsible for shaping branding in line with the organization's strategy. (Sandler, 2005: 15).

Employer Branding includes both tangible features such as salary, rewards, and benefits and intangible assets such as an 'organization's culture, values, management style, and employee development opportunities (Dawn and Biswas, 2010: 21). However, according to Reychav and Sharkie (2010: 227), trust in management, psychological support, management values, and rewards are strong priorities of employee perceptions. These are positively associated with the extra-role behaviors of the employees. Therefore, other priorities, other than financial expectations, may be effective. In the analysis, organizational commitment and employer branding are in a statistically insignificant relationship in most of its subdimensions. Similar to this result, Vaijayanthi et al.'s (2011: 91) research results show a positive but statistically insignificant relationship between employer brand and organizational 
commitment. Priyadarshi (2011: 510) examined the employer brand in his study. He suggested that the current organizational environment impacts the emotional engagement negatively. Therefore attention should be paid to creating opportunities to foster informal culture and roles.

\section{CONCLUSION}

In this study, where the effects of organizational culture and organizational commitment of the employees were investigated in relation with employer branding for the companies operate in Istan bul, Turkey. The influence of the company managers on employer brand operating was analyzed. As a result of the analysis, the relationship between organizational culture, organizational commitment, and employer brand were clearly defined. This study is important for expressing managers' and employees' opinions about employer brand activities.

As a result of the correlation analysis that was conducted to determine the employer brand relationship with the organizational culture and organizational commitment. According to the findings, significant relationships were obtained between the variables of participation, consistency, adaptability, and organizational culture, which are the variables of employer brand scale, career opportunities, development, working environment, business characteristics, work,-life balance, salary and other financial benefits.

Five regression models were created to determine the effects of organizational culture and organizational commitment. Employer brand and sub-dimensions are dependent variables; organizational culture and organizational commitment were independent variables. As a result of this analysis, organizational commitment was obtained as the most important determinant of the relationship between the employer brand and the employees. By establishing strong organizational commitment, belonging to the organization will be created for the employees, and the turnover will be reduced.

In the future research, international organizations can be analyzed and the differences between the findings for Turkish companies can be compared with international ones. The impact of culture on organizational commitment can also be investigated. At the same time, the differences between public and private sectors in terms of organizational commitment can be researched.

There are a number of limitations that the effect of gender can be identified for establishing strong bonds for enhancing employer branding. Male and female employees may be effected differently by the organizational culture and commitment. Additionally the 
difference between various sectors can be examined in the future research to understand the outcomes are valid for this sector or they can be generalized for other sectors.

\section{REFERENCES}

Armstrong, M. (2001), "Human Resource Management: Strategy and Action", London: Korgan Publishing.

Backhaus, K.,Tikoo, S., (2004), "Conceptualizing and researching employer branding”, The Emerald Research, 9(5), 501-517.

Bahadır, G., Özgülnar, N., Kantarcıoğlu, N., Ay, P., (2008). "İstanbul Tıp Fakültesi öğrenci ve hekimlerinin tıpla ilgili tutumlarının duygusal anlam ölçeği kullanılarak incelenmesi”, Tıp Eğitimi Dünyast, 28.

Balay, R., (2012), "Effect of learning organization perception to the organizational commitment: A comparison between private and public university", Educational Sciences: Theory and Practice, 12(4), 2474-2486.

Barrow, S., R. Mosley, (2005), "The Employer Brand: Bringing the Best of Brand Management to People at Work", New Jersey: John Wiley\&Sons, Inc.

Baysal, C., Tekarslan E., (1996), "Behavioral Sciences for Operators", Istanbul: Avc1yol Basin Yayın.

Bonaiuto, M., De Dominicis, S., Illia, L., Rodríguez-Cánovas, B., Lizzani, G., (2013), "Managing employer brand attributes to attract potential future leaders, Journal of Brand Management", 20(9), 779-792.

Bruce, D., Harvey, D., (2010), “Marka Bilmecesi”, İstanbul: Türkiye İş Bankası Kültür Yayınlar1.

Burke, R. J., Cooper, C. L., (2006), "The new world of work and organizations: Implications for human resource management”, Human Resource Management Review, 16 (2), 83-85.

Chappell, S. F., (2011), "Exploring the relationship of meaning-making structure, emotional intelligence, IQ and managerial-leadership effectiveness", Doctoral dissertation, University of Western Australia.

Collins, C.J., Kanar, A.M., (2013). "Employer Brand Equity and Recruitment Research-The Oxford Handbook of Recruitment", Newyork: Oxford University Press.

Çetin, M. Ö., (2006). "The relationship between job satisfaction, occupational and organizational commitment of academics", The Journal of American Academy of Business, 8 (1), 78-88.

Dabirian, A., Paschen, J., Kietzmann, J., (2019), "Employer branding: Understanding employer attractiveness of IT companies", IT Professional, 21(1), 82-89.

Dawn, S.K., Biswas, S., (2010), "Employer branding: A new strategic dimension of Indian corporations", Asian Journal of Management Research, 21-33.

Demir, N., (2011), “Örgüt Kültürü ve İş Tatmini”, İstanbul: Türkmen Kitabevi.

Erdoğan, İ., (1999), “İşletme Yönetiminde Örgütsel Davranış”, İstanbul: Beta Basım Dağıtım ve Yayınevi.

Eren, E., (2004), “Örgütlerde Davranış ve Yönetim Psikolojisi”, İstanbul: Beta Yayınları. 
Ewing, M. T., Pitt, L. F., de Bussy, N. M., Berthon, P., (2002), "Employment branding in the knowledge economy", International Journal of Advertising, 21(1), 3-22.

Greenberg, J., Baron, R.A., (2000), "Behavior in Organizations", New Jersey: 7th Edition, Prentice-Hall.

Güney, S. (2011), “Örgütsel Davranış”, Ankara: Nobel Yayınları.

Hoppock, R., (1935), “Job satisfaction”, Harper.

Iivari, J., Iivari. N., (2011), "The relationship between organizational culture and the development of agile methods", Information Software Technology, 53(5), 509-520.

Kara, M. N., (2013), "İşveren Markası İle Örgütsel Bağlılık Arasındaki İlişki: Bilişim Sektöründe Bir Uygulama”, Yayınlanmamış yüksek lisans tezi, Uludağ Üniversitesi Sosyal Bilimler Enstitüsü, Bursa.

Kızıloğlu, M., Bayrak Kök, S., (2017), "Denison örgüt kültürü modeli üzerine bir araştırma”, ASEAD, 4(11), 141-159.

Kuruüzüm, A., Sezgin, I., Çetinipekçi, E., (2010), "İşe Bağl1lı̆̆1 Etkileyen Faktörler: İmalat ve Hizmet Sektörlerinde Karşılaştırmalı Bir Analiz”, Bilig, 53, 183-198.

Küçükgökdemir, A. C., Bal, Y., (2018), “İşveren Markası ve İşveren Markasının İşe Alım Üzerindeki Etkisi" Proceedings of INTCESS2018- 5th International Conference on Education and Social Sciences, 5-7 February 2018, İstanbul, 1094-1101.

Locke, E.A., (1976), "The Nature and Causes of Job Satisfaction", M.D. (Ed.), Handbook of Industrial and Organizational Psychology, Rand McNally, Chicago, IL, 1297-349.

Lockwood, N. R., (2007), "Leveraging employee engagement for competitive advantage: HR s strategic role", SHRM Research Quarterly.

Minchinglon, B., Thome, K., (2007), "Measuring the effectiveness of your employer brand", Human Resources, 14-16.

Mokina, S. (2014). "Place and role of employer brand in the structure of corporate brand." Economics \& Sociology, 7(2), 136-148.

Mowday, R.T., Porter, L.W., (1979). "The measurement of organizational commitment", Journal of Vocational Behavior, R.M. Steers, 14(2), 224-247.

Öksüz, B., (2012). "İşletmelerde Örgütsel Çekiciliğin Arttırılmasında İşveren Markalaşması ve İnsan Kaynaklarına Yansıması", Doktora tezi, Ege Üniversitesi, Sosyal Bilimler Enstitüsü, Halkla Ilişkiler ve Tanıtım Anabilim Dalı, İzmir.

Özkalp, E., Kırel, Ç., (2010). “Örgütsel Davranış”, Bursa: Ekin Basım Yayın Dağıtım.

Özutku, H., (2009). "Örgüte duygusal devamlılık ve normatif bağlılık ile iş performansı arasındaki ilişkinin incelenmesi". İstanbul Üniversitesi İşletme Fakültesi Dergisi, 37 (2), 7997.

Porter, L.W., Steers, R.M., Mowday, R.T., Boulian, R.T., (1974), "Organizational commitment, job satisfaction, and turnover among psychiatric technicians", Journal of Applied Psychology, 59(5), 603-609.

Priyadarshi, P., (2011), "Employer brand 1mage as predictor of employee satisfaction, affective commitment \& turnover", Indian Journal of Industrial Relations, 46(3), 510-522. 
Ramdhani, A., Ramdhani, M.A., Ainissyifa, H., (2017), "Conceptual framework of corporate culture influenced on employees commitment to organization", International Business Management, 11(3), 826-830.

Reychav, I., Sharkie, R., (2010). "Trust: An antecedent to employee extra-role behaviour", Journal of Intellectual Capital, 11(2), 227-247.

Robbins, S. P., Judge, T., (2007). "Organizational Behavior", Upper Saddle River, N.J: Pearson/Prentice Hall.

Sandler, S. F., (2005). "Hr brand building in ' 'today's market", HR Focus, 82(2), 15.

Schein, E.H., (2010). "Organizational Culture and Leadership”, The Jossey-Bass Business \& Management Series, Jossey-Bass.

Tanwar, K., Prasad, A., (2016). "The effect of employer brand dimensions on job satisfaction: gender as a moderator", Management Decision, 54(4), 854-886.

Tatar, B., Müceldili, B., Erdil , O., (2018). "Does employer branding affect job embeddedness? The mediating role of dedication and perceived organizational support". Business \& Management Studies: An International Journal, 6(3): 346-361.

Vaijayanthi, P., Roy, R., Shreenivasan, K.A., Srivathsan, J., (2011)." Employer branding as an antecedent to organisation commitment: an empirical study", International Journal of Global Business, 4(2), 91-106.

Van Hoye, G., Baş, T., Cromheecke, S., Lievens, F., (2013), "The instrumental and symbolic dimensions of 'organisations' image as an employer: A large-scale field study on employer branding in turkey", Applied Psychology, 62(4), 543-557.

Vural, Z. B., (2003). “Kurum Kültürü̈, İstanbul: İletişim Yayınları.

Wasti, A., (2000). “Örgütsel bağlılığ belirleyen evrensel ve kültürel etmenler: türk kültürüne bir bakış, türkiye'de yönetim, liderlik ve insan kaynakları uygulamaları”, Türk Psikologlar Derneği Yayınları, 21, Ankara.

Wolf, M., Sims, J., Yang, H., (2015), “Look ' 'Who's Co-Creating: Employer Branding on Social Media", ECIS 2015 Completed Research Papers, AIS Electronic Library, http://eprints.bbk. ac.uk/19471/1/19471.pdf. 